\title{
Research on evaluation of port railway collection and transportation system
}

\author{
Shang Chuanjing ${ }^{1, \mathrm{a}}$, Li Ziwei ${ }^{1, \mathrm{~b}}$, Wang Juan ${ }^{1, \mathrm{c}}$, Liu Guoliang ${ }^{1, \mathrm{~d}}$ and Du Xiaodong ${ }^{1, \mathrm{e}}$ \\ ${ }^{1}$ Logistics Department, Shandong Jiaotong University, Jinan, Shandong Province, 250357, China
}

\begin{abstract}
Ports play an essential role in economic and trade, which is an important node and hub in cargo transportation. The important evaluation index of port competitiveness is the efficiency of port collection and distribution system. This paper analyzes the development trend of port collection and distribution system. According to the principle of establishing evaluation index, a reasonable evaluation index system of port collection and transportation system is constructed. The port collection and distribution system as a whole. The index system of port transportation capacity, service level, coordination ability with port and external conditions are constructed. Finally, the paper analyzes the operation process of collection and distribution system of Port A
\end{abstract}

\section{Introduction}

Port is an important transportation infrastructure and a combination of various modes of transport. The port has borne $80 \%$ to $90 \%$ of the total import and export freight volume in China, and has loaded and unloaded $99 \%$ of the imported iron ore and $95 \%$ of the imported crude oil. Port throughput has been growing rapidly in recent years. The rapid growth of port throughput not only puts forward higher requirements for port infrastructure, but also brings more challenges to the further improvement of port storage and transportation system. In all aspects of the port collection and distribution system ${ }^{[1]}$," collection "means the delivery of goods to be exported (transported) to the port according to the location designated by the consignor and the centralized stacking of goods in the front or nearby yard of the wharf;" sparse" means the unloading of imported goods from the ship to the yard or warehouse behind the wharf, or directly from the ship to the vehicle, and then to the consignee's destination by some kind of collection and distribution. It can be seen that the port collection and distribution system is an important system for the survival and development of the port, an important channel for the port to connect with its hinterland, and a major artery for the economic energy transmission of the port. Under the background of "Belt and Road" construction, a port area, as the node of "Belt and Road" and the outlet of northwest China, opens up the port logistics channel, realizes the support to the hinterland economy, and connects the sea-rail transport. It becomes a port area logistics rapid development of new.

\section{Development Analysis of Port Collection and Transportation System}

Collection and distribution system refers to all kinds of transportation modes within the scope of socialized and reasonable division of labor, follow the economic characteristics of their respective modes of transportation, and form a complex of mutual division of labor, cooperation and integration of transportation. Port collection and distribution system refers to the transportation system connected with the port to concentrate and evacuate the cargo. The development of the collection and distribution system of our ports is shown below.

\subsection{Proportion of coordinated water, public and iron distribution modes}

According to the actual situation of each port, coordinate the proportion of water, public and iron. In our country, the proportion of highway transportation mode is too large, and the long distance transportation is generally carried out by highway transportation, which not only makes the cost consumption higher, but also more pollution to the external environment. Accordingly, in the future development of each port collection and distribution system, the proportion of these three modes of collection and distribution is reasonably matched reasonably matched to reduce the of dependence on the single mode of collection and distribution.

\footnotetext{
* Corresponding author: ${ }^{2} 2647972655 @ q q . c o m$

b2635054973@qq.com

c2586570427@qq.com

d1975666841@qq.com

e1780099403@qq.com
} 


\subsection{Attach importance to the development of inland river transportation}

According to the contents of inland river planning in China's national planning, it can be seen that inland rivers will have large-scale development. Make full use of the advantages of inland rivers to alleviate the disadvantage of excessive proportion of highway collection and transportation.

\subsection{Attach importance to the development of railway transportation}

Focus on the development of railway transport, strengthen sea-rail transport and sea-river transport. Although the choice of railway transportation has been paid more attention to in our country, its development still lags behind. Therefore, in the future development of railway transportation system, we will make full use of the advantages of railway transportation and increase the proportion of investment in railway transportation.

\subsection{Port Collection and Transportation System towards Green Direction}

On the basis of pursuing the rapid growth of port throughput, our ports pay more and more attention to the environmental protection of ports. Therefore, the choice of transportation mode will reduce the choice of transportation mode of polluted highway and increase the choice of environment-friendly railway and waterway transportation mode.

\section{Determination of Evaluation Index of Port Railway Collection and Transportation System}

\subsection{Composition of the port railway transport system}

Port collection and distribution system refers to the transportation system connected with the port to concentrate and evacuate the cargo. The port transportation system includes three $\operatorname{aspects}^{[2]}$ : transportation mode, transportation facilities and transportation management, in which the transportation mode is determined by the transportation passage; the transportation facilities are mainly composed of transportation means and transportation nodes; and the transportation management refers to the organization, coordination and formulation of transportation plan in order to make various transportation modes connect well with each other. The composition of the specific port collection and distribution system is shown in figure 1 .

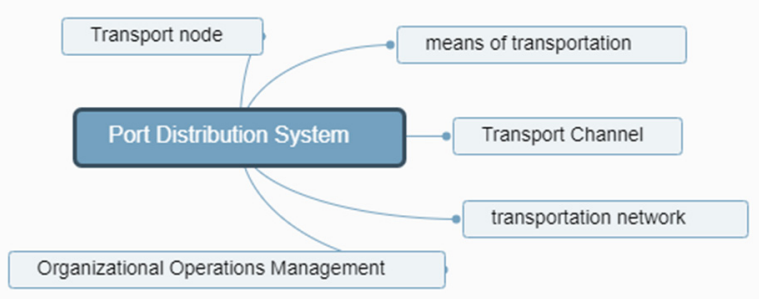

Fig. 1. Components of the port distribution system

\subsection{Principles for determining evaluation indicators}

By establishing a complete, strict and scientific index system, the research on port collection and distribution system must show all aspects of port collection and distribution system, and then understand port collection and distribution system in different ports ${ }^{[3]}$.

Scientific principles. The index of port collection and distribution system is composed of some related and independent indexes, and the quantitative calculation method of series indexes reflected by port collection and distribution system should be scientific and reasonable.

The principle of comprehensive unity. In the evaluation index system, it is required to pick out the representative comprehensive indexes from all aspects of the port collection and transportation system, and all these indexes should be able to form an internal unity.

Principle of comparability. When comparing the collection and distribution systems of different ports, the evaluation index must have certain scientific clarity in terms of scope, meaning, calculation method, content and so on, in order to reduce the errors in the process of collecting and statistics indicators.

Operational principle. First, the relevant data of the index can be obtained by consulting the data or carrying out the relevant investigation; secondly, the obtained index can be easily quantified, and the qualitative index can be carried out by calculating the transformation or assignment method.

Guiding principles. Through the evaluation of the index of port collection and distribution system, the main purpose is to make the port collection and distribution system improve and develop in a more reasonable direction.

\subsection{Determination of evaluation indicators}

Combined with the characteristics of the existing port collection and distribution system ${ }^{[4]}$, the evaluation index system of the port collection and distribution system is constructed according to the principle of establishing the evaluation index. The evaluation index of port railway transportation system is set up as shown in Table 1, Figure 2. 


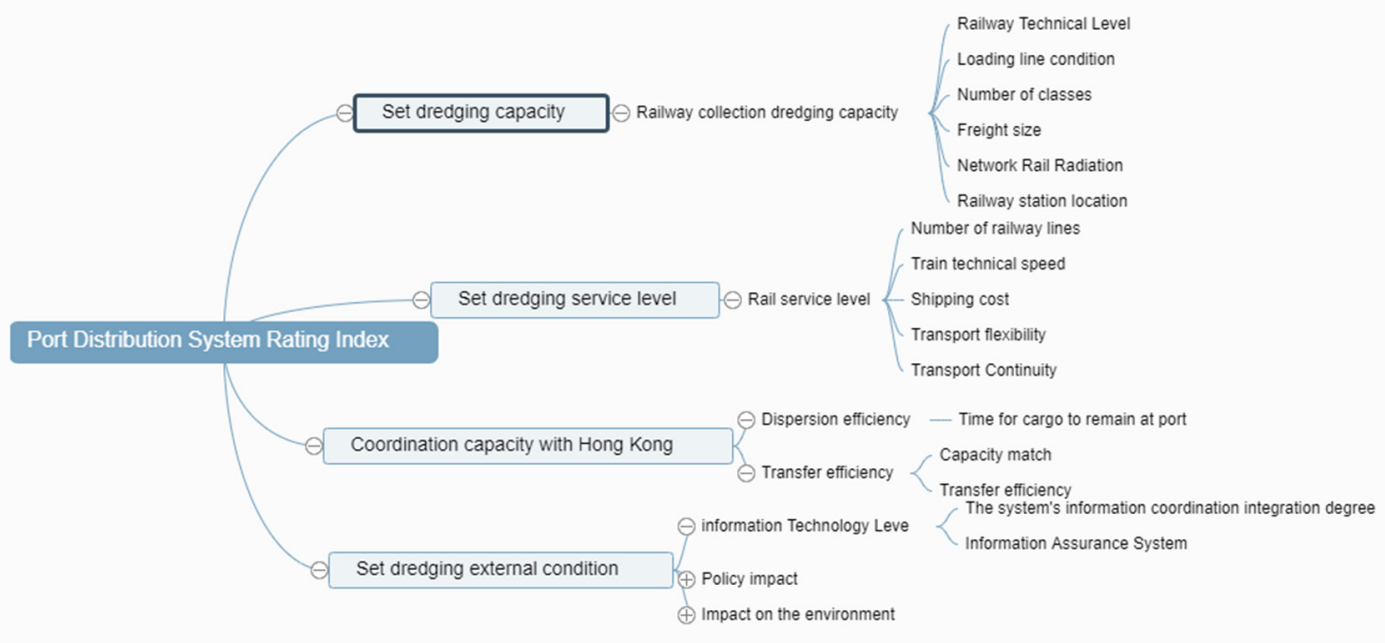

Fig. 2. Structure of Rating Index of Port Distribution System

Table 1. List of rating indicators for port collection dredging systems

\begin{tabular}{|c|c|c|}
\hline $\begin{array}{l}\text { Level 1 } \\
\text { indicators }\end{array}$ & $\begin{array}{l}\text { Secondary } \\
\text { indicators }\end{array}$ & $\begin{array}{l}\text { Three levels of } \\
\text { indicators }\end{array}$ \\
\hline \multirow{5}{*}{$\begin{array}{c}\text { Set } \\
\text { dredging } \\
\text { capacity A }\end{array}$} & \multirow{5}{*}{$\begin{array}{l}\text { Railway } \\
\text { collection } \\
\text { dredging } \\
\text { capacity A1 }\end{array}$} & $\begin{array}{l}\text { Railway Technical Level } \\
\text { A11 } \\
\text { Loading line condition } \\
\text { A12 }\end{array}$ \\
\hline & & Number of classes A13 \\
\hline & & Freight size A14 \\
\hline & & $\begin{array}{l}\text { Network Rail Radiation } \\
\text { A15 }\end{array}$ \\
\hline & & $\begin{array}{l}\text { Railway station location } \\
\text { A16 }\end{array}$ \\
\hline \multirow{5}{*}{$\begin{array}{l}\text { Set } \\
\text { dredging } \\
\text { service } \\
\text { level B }\end{array}$} & \multirow{5}{*}{$\begin{array}{l}\text { Rail service } \\
\text { level B1 }\end{array}$} & $\begin{array}{l}\text { Number of railway lines } \\
\text { B11 }\end{array}$ \\
\hline & & $\begin{array}{l}\text { Train technical speed } \\
\text { B12 }\end{array}$ \\
\hline & & Shipping cost B13 \\
\hline & & Transport flexibility B14 \\
\hline & & Transport Continuity B15 \\
\hline \multirow{3}{*}{$\begin{array}{l}\text { Coordinati } \\
\text { on } \\
\text { capacity } \\
\text { with Hong } \\
\text { Kong C }\end{array}$} & $\begin{array}{c}\text { Dispersion } \\
\text { efficiency C1 }\end{array}$ & $\begin{array}{l}\text { Time for cargo to remain } \\
\text { at port } \mathrm{C} 11\end{array}$ \\
\hline & $\begin{array}{r}\text { Transfer } \\
\text { efficiency C2 }\end{array}$ & Capacity match C22 \\
\hline & & Transfer efficiency C22 \\
\hline \multirow{4}{*}{$\begin{array}{c}\text { Set } \\
\text { dredging } \\
\text { external } \\
\text { condition } \\
\text { D }\end{array}$} & $\begin{array}{l}\text { Information } \\
\text { Technology } \\
\text { Level D1 }\end{array}$ & $\begin{array}{l}\text { The system's information } \\
\text { coordination integration } \\
\text { degree D11 }\end{array}$ \\
\hline & & $\begin{array}{l}\text { Information Assurance } \\
\text { System D12 }\end{array}$ \\
\hline & $\begin{array}{r}\text { Policy } \\
\text { impact D2 }\end{array}$ & Policy Guidance D21 \\
\hline & $\begin{array}{l}\text { Impact on } \\
\text { the environment } \\
\text { D3 }\end{array}$ & $\begin{array}{l}\text { Impact on the } \\
\text { environment D31 }\end{array}$ \\
\hline
\end{tabular}

\section{Analysis of Operation Flow of A Port Railway Collection and Distribution}

A port is an important part of international trade center and international logistics center in B area. A port area has geographical advantages, as a bridgehead connecting Northeast Asia, with its natural deep-water port advantages, actively participate in the construction of "Belt and Road ", committed to build the most developed port of China's supporting railways, Vigorously promote iron ore" rail "transport mode reform.

\subsection{A Port Railway Collection and Transportation System Collection and Transportation Operation Process}

A port railway transportation system refers to the railway two-way transportation system which is connected with the port area and provides the freight collection and transportation service in the port area. The collection and transportation system refers to the loading of goods (mainly coal) from the inland hinterland source station, through the Qiancao Railway, Zhangtang Railway to the A North Station, through the railway (Caoxi Line) into the port station (mainly A West Station) for unloading operations, and stacked in the front of the wharf or near the wharf yard. Taking coal as an example, the coal collection operation flow of A port railway collection and distribution system is shown in figure 3 . 


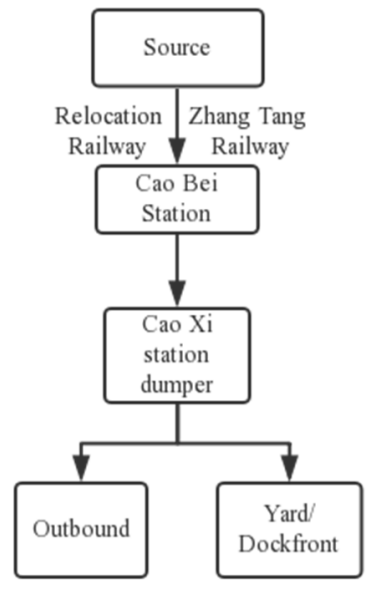

Fig. 3. Flowchart of Railway Collection and Transportation System in Port Area

\subsection{A Operation Process of Port Railway Collection and Transportation System}

The dredging system refers to the loading operation of the port disembarkation cargo (mainly iron ore) organized by the A South Station, entering the A North Station through the Cao South Line, and unloading the vehicle through the Cao Cao Railway to the final station. The ore distribution operation flow of the railway collection and distribution system in the port area is shown in figure 4.

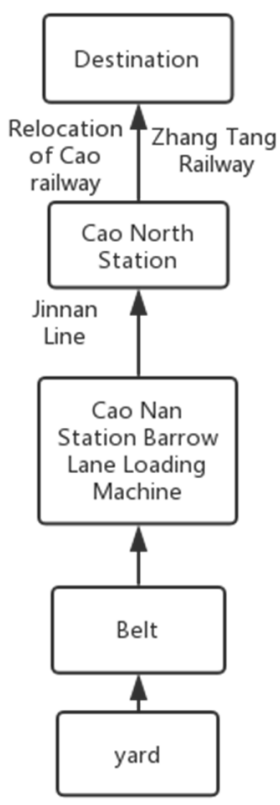

Fig. 4. Flowchart of Distribution System in Port Area

In the railway collection and distribution system of Hong Kong area, the railway lines are mainly divided into Jishugang trunk railway (Qian Cao railway and Zhangtang railway) and port railway (Caoxi line and Cao Nan line).

\section{Countermeasures of A Port Development Railway Collection and Distribution System}

Under the background of "Belt and Road" construction, A port area, as the node of "Belt and Road" and the outlet of northwest China, opens up the port logistics channel, realizes the support to the hinterland economy, and connects the sea-rail transport. The following suggestions are put forward for the development of railway transportation system in port area ${ }^{[5]}$.

The port should speed up the infrastructure construction of railway collection and distribution system, and get through the "last kilometer". The construction of the external railway collection and distribution system in the port area is becoming more and more perfect, the Qian Cao Line, Tang Hu Line and Tang Cao Line have been opened to traffic, and the Shuicao Railway is under construction.

The port should increase the construction of logistics channel to the sea, and increase the number of liner routes. The domestic trade routes in A port area cover major coastal and river ports such as East China, South China, Fujian and Hainan, and export routes are connected with more than 120 ports of the world.

The port should strengthen the information construction of the railway collection and distribution system, build a smart port, improve the information level of the railway collection and distribution system, speed up the construction of the information platform, effectively reduce the logistics cost.

\section{Conclusions}

As the transportation system of port centralized and evacuation cargo service, port railway transportation system is the key to control the efficiency and benefit of port logistics service. Therefore, it is of great significance to ensure the perfection of port collection and transportation system for the continuous and rapid development of the port. In this paper, the evaluation index system of port transportation system is constructed from the aspects of capacity, service level and coordination ability. To a certain extent, it makes up for the deficiency of the evaluation system of port collection and transportation system in the past. This paper holds that the future development trend will be to improve the evaluation index system, expand the research scope and study the policies and measures in the construction of the evaluation system of port collection and transportation system.

\section{References}

1. Lu Chunhui. (2020) Analysis on Cooperative Management Mode of Port Coal Logistics Collection \& Distribution System. Boao observation.

2. Kang Qian. (2020)A Preliminary Reflection on Strengthening the Basic Role of Vehicle Specialty in the Collection and Distribution System of Beijing- 
Tianjin-Hebei Port Ore Powder Railway. Encyclopedia Forum Electronic Journal.

3. Zhou Xiaowen. (2005)Analysis and Countermeasure on Capacity of Collection and Distribution Channel of Da-Qin Railway. Railway Economic Research.

4. Wang Chunlei. (2013)Discussion on the Design of
Heavy-haul Railway Unloading Station with Trucking Machine. Unloading Railway freight.

5. Wu Liuyi. (2018) Evaluation on Coordination of Railway Distribution System in Caofeidian Port Area. Beijing Jiaotong University. 